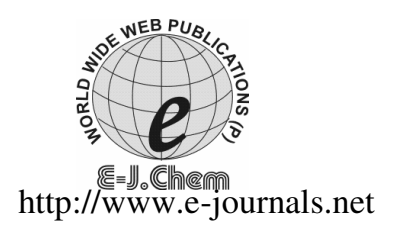

ISSN: 0973-4945; CODEN ECJHAO
E-Journal of Chemistry
2010, 7(4), 1340-1345

\title{
Conversion of Waste into Wealth: A Study in Solid Waste Management
}

\author{
T. JANAKIRAM and K. SRIDEVI \\ P.G and Research Department of Chemistry, \\ Kurinji College of Arts and Science, \\ Tiruchirappalli- 620 002, Tamilnadu, India. \\ contactjanakiram@yahoo.com
}

Received 5 April 2010; Accepted 20 May 2010

\begin{abstract}
Disposal of solid waste has been the talk of the day. An attempt has been made to dispose of the solid waste Jatropha (Kattamanakku). Aerobic composting method was employed. Properly treated solid wastes of different composition were mixed with slurries of cowdung and physicochemical parameters were measured after 30 and 60 days of composting. It was observed that percentages of nitrogen, phosphorous, potassium, sodium, calcium and magnesium increased as time elapsed. Water holding capacity, electrical conductivity and moisture content were found to increase, while $\mathrm{pH}$ and $\mathrm{C} / \mathrm{N}$ ratio have been observed to decrease.
\end{abstract}

Keywords: Jatropha, Composting, Waste disposal, Maturity of the compost, Physicochemical parameters.

\section{Introduction}

Solid waste is considered to be wastes such as garbage, industrial waste, sewage sludge, ashes, discarded metal, trash on any solid or semi solid material. Solid waste disposal has been an issue facing humans since they began living together in large permanent settlements. With the migration of people to urban settlements, the volume of solid waste in concentrated areas is increased.

Composting ${ }^{1}$ is an aerobic, biological process that uses naturally occurring microorganisms to convert biodegradable organic matter into humus like product. The process destroys ${ }^{2}$ pathogens, converts nitrogen from unstable ammonia to stable organic farms and reduces the volume of the waste. Presently composting has become an important method to dispose of solid wastes.

Aerobic composting ${ }^{3}$ is a technology of quick disposal of garbage and desirable recycling process because considerable portion of municipal solid waste is biodegradable material and with high moisture content.

Much of the research on composting has focused on the changes in the physical and chemical parameters of the compost primarily in an effort to find a simply and reliable indicator of compost maturity and to improve the efficiency of the process. The purpose of this study is to 
provide a better understanding of the physical and chemical factors which may influence microbial activity in composting. The solid waste Jatropha used in the study is a genus of approximately 175 succulent plants, shrubs and trees from the family of Euphorbiaceae.

The physical parameters namely moisture content (MC), water holding capacity (WHC) and bulk density (BD) and chemical parameters such as $\mathrm{pH}$, electrical conductivity (EC), organic carbon and contents of nitrogen, phosphorous, potassium, sodium, calcium and magnesium, have been examined for the study.

\section{Experimental}

The solid waste Jatropha (Kattamanakku) was collected from Alangudi Mahajanam, Lalgudi taluk, Tamilnadu, India. The material was properly dressed. Composting was performed in plastic tubs. Slurries of cowdung were added to different tubs, each containing a particular proportion of solid waste and cowdung. The material was allowed to compost. The material was moistened once in a week.

The composting was allowed to continue for a period of 30 and 60 days. Samples were collected at the end of these periods and examined for various physical and chemical parameters.

The $\mathrm{pH}$ and electrical conductivity (EC) of the samples were measured by preparing suspension of $20 \mathrm{~g}$ matter in $100 \mathrm{~mL}$ of deionised water, using $\mathrm{pH}$ meter and conductivity meter. Making use of a flame photometer the percentage of total sodium and potassium were determined. The percentage of phosphorous was determined with the help of photo electric colorimeter.

Estimation of nitrogen, calcium, magnesium and organic carbon was carried out by usual methods ${ }^{4}$. In addition the parameters like bulk density moisture content and water holding capacity were evaluated. The results were tabulated.

\section{Results and Discussion}

In the present study composted samples containing cowdung and solid waste of different proportions have been studied. The physical parameters were determined and tabulated. The chemical parameters were evaluated. These are presented in Tables 1 and 2.

\section{Bulk density}

Bulk density ${ }^{5}$ is a measure of the weight per unit volume of a substance $\left(\mathrm{kg} / \mathrm{m}^{3}\right)$. Materials with a high bulk density typically have very few air spaces with most of the fine pores filled with water. Under these conditions bacteria which grow in the absence of oxygen will predominate producing methane and other foul smelling gases. Mixing manures with low bulk density improves air exchange minimizing the need for artificial aeration. In the various samples used, the bulk density ranges from 219.6 to $275.1 \mathrm{~kg} \mathrm{~m}^{-3}$. Since these values are not high, so that the condition for the bacterial growth is prevented.

Table 1. Physical parameters of the samples studied

\begin{tabular}{|c|c|c|c|c|c|c|c|}
\hline \multirow[b]{2}{*}{ S.No. } & \multirow[b]{2}{*}{ Parameter } & \multicolumn{2}{|c|}{ Sample 1} & \multicolumn{2}{|c|}{ Sample 2} & \multicolumn{2}{|c|}{ Sample 3} \\
\hline & & $\begin{array}{c}30 \\
\text { days }\end{array}$ & $\begin{array}{c}60 \\
\text { days }\end{array}$ & $\begin{array}{c}30 \\
\text { days }\end{array}$ & $\begin{array}{c}60 \\
\text { days }\end{array}$ & $\begin{array}{c}30 \\
\text { days }\end{array}$ & $\begin{array}{c}60 \\
\text { days }\end{array}$ \\
\hline 1. & Electrical conductivity, $\mathrm{dsm}^{-1}$ & 8.70 & 11.04 & 7.39 & 10.77 & 7.00 & 8.73 \\
\hline 2. & Bulk density $\times 10^{-3} \mathrm{~kg} \mathrm{~m}^{-3}$ & 0.2196 & 0.2258 & 0.2411 & 0.2728 & 0.2418 & 0.2751 \\
\hline 3. & Moisture content, $\%$ & 15.65 & 18.82 & 12.30 & 16.43 & 12.31 & 16.35 \\
\hline 4. & Water holding capacity, $\%$ & 169.55 & 181.32 & 120.75 & 153.35 & 118.32 & 135.26 \\
\hline
\end{tabular}


Table 2. Chemical parameters of the samples studied

\begin{tabular}{clcccccc}
\hline \multirow{2}{*}{ S.No } & \multirow{2}{*}{ Parameter } & \multicolumn{2}{c}{ Sample 1 } & \multicolumn{2}{c}{ Sample 2 } & \multicolumn{2}{c}{ Sample 3 } \\
\cline { 3 - 8 } & & 30 days & 60 days & 30 days & 60 days & 30 days & 60 days \\
\hline 1. & pH & 7.56 & 7.32 & 7.44 & 7.23 & 7.59 & 7.37 \\
2. & Organic carbon, \% & 6.95 & 13.5 & 5.13 & 14.5 & 4.13 & 14.82 \\
3. & Total nitrogen, \% & 0.81 & 1.26 & 0.61 & 1.50 & 0.53 & 1.22 \\
4. & Total phosphorous, \% & 0.71 & 0.32 & 0.20 & 0.365 & 0.29 & 0.40 \\
5. & Total potassium, \% & 1.53 & 1.70 & 1.66 & 1.80 & 1.61 & 1.78 \\
6. & Total calcium, \% & 0.48 & 0.52 & 0.51 & 0.53 & 0.52 & 0.56 \\
7. & Total magnesium, \% & 0.31 & 0.33 & 0.42 & 0.43 & 0.43 & 0.44 \\
8. & Total sodium, \% & 0.26 & 0.27 & 0.26 & 0.28 & 0.28 & 0.30 \\
9. & C / N ratio & $8: 1$ & $11: 1$ & $8: 1$ & $10: 1$ & $7.5: 1$ & $12: 1$ \\
\hline
\end{tabular}

\section{Water holding capacity}

Water holding capacity (WHC) is the amount of water held into pores after gravitation loss for a specified time. This test is assessed to find the utilization of compost for growing media. In the study carried out WHC has been observed to increase. This reveals that the amount of water held in pores increases with days of composting ${ }^{6}$.

\section{Moisture content}

Just like people, compost organisms need water to live. Some micro organisms use the film of water to move slipping and sliding to another section of the pile. Biological activity stops when the pile dries out. If adequately aerated, composting material with moisture content between $30 \%$ and $100 \%$ will be aerobic. In practical aerobic composting, however high moisture content must be avoided because water displaces air from the interstices between the particles causing anaerobic conditions. However too low moisture content deprives organisms of water needed for their metabolism and inhibits their activity. Moisture content for satisfactory aerobic composting varies with material used. In the samples studied the percent moisture content varies from 12.30 to 18.82 . Since it is lesser than $30 \%$ adequate aeration has been taken care of ${ }^{7}$.

\section{Calcium and magnesium}

Calcium has strong influence on ion absorption by soil particle and on the availability of other elements. Calcium is important in the formation of plant cell walls and in the layers between the cells is called middle lamella.

Magnesium is closely related to calcium and is absorbed in the soil as anion. It involves in energy conversion and phosphorous metabolism. The percentages of calcium and magnesium for the various samples studied have been observed to increase as the time of composting increased. This shows that the composted material obtained when used for growing plants will have the capability to supply other elements for the solid and the ion absorption by soil particle will be enhanced ${ }^{8}$. The composted material also helps in energy transfer and phosphorous metabolism.

\section{Nitrogen, phosphorous, sodium and potassium}

The essential elements for the growth of any plant are nitrogen, phosphorous, sodium and potassium. All these elements play a significant role if used in the form of a manure (or) 
fertilizer. Since composting finally leads to organic manure it is worthwhile in estimating these elements in the composted material obtained after a period of 30 and 60 days.

In the various samples of the solid wastes that have been studied, it is observed that as the days of decomposition increased there is an increase in the percentage of nitrogen, phosphorous, sodium and potassium. These results indicate that the efficiency of the organic manure is a measure of the days of decomposition. Thus the production of very useful manure requires lengthening of composting process.

The content of potassium increases during the period of composting. Effective use of some fibrous material like straw or wood chips which can absorb relatively large quantities of water and still maintain structural integrity and porosity could prevent the loss of potassium from the compost formed ${ }^{9}$.

Phosphorous content gradually increases during composting process. The water solubility of phosphorous decrease with humification so that phosphorous solubility during the decomposition was subjected to further immobilization factor ${ }^{10}$.

\section{C/N ratio}

$\mathrm{C} / \mathrm{N}$ ratio is one of the most important parameters that determine the extent of composting and degree of compost maturity. Irrespective of the materials used for the composting all treatments attained drastic decrease of $\mathrm{C}: \mathrm{N}$ ratio in final product compared to initial raw materials. This shows higher decomposition in kattamanakku compost.

The $\mathrm{C} / \mathrm{N}$ ratio below 20 can be considered satisfactory for compost maturity. When the initial C:N ratio is in between 25 and 30, most of the compost recipies in the present study had a $\mathrm{C}: \mathrm{N}$ ratio below 20 and hence are considered matured.

The $\mathrm{C} / \mathrm{N}$ ratio is used as an index for maturity of organic wastes. According to Senesi, decline in $\mathrm{C} / \mathrm{N}$ ratio less than 20 indicates an advanced degree of organic matter stabilization and reflect a satisfactory degree of maturity of organic wastes ${ }^{11}$.

\section{Electrical conductivity}

The electrical conductivity in matured aerobic compost increased as the days progressed which may be due to high microbial activity and mineralization, so that soluble salt content is high.

$p H$

$\mathrm{pH}$ Generally gives and approximate index of compost maturation. Manure composts tend to have near neutral $\mathrm{pH}$ values, while composts under maturation tend to be more acidic. Averagely mature composts have $\mathrm{pH}$ between 6 and 8 and the composts prepared have $\mathrm{pH}$ in this range indicating maturity of the compost.

Haimi and Huhta have postulated that lower $\mathrm{pH}$ in the final vermicomposts might be due to the production of $\mathrm{CO}_{2}$ and organic acids by microbial activity during the process of bioconversion of different substrates in the feed given to earthworm ${ }^{12}$.

\section{Statistical analysis}

In the case of physical parameters the values EC, BD, MC\& WHC are found to increase as composting is prolonged (Table 3). The $t$ test reveals the EC and MC are significant. Except $\mathrm{pH}$, the values of all other chemical parameters increase as the days of composting prolonged. Except in the case of total magnesium it has been observed that the other chemical parameters are quite significant. 
Table 3. Statistical analysis of various parameters

\begin{tabular}{|c|c|c|c|c|c|c|c|}
\hline \multirow{3}{*}{ S.No. } & \multirow{3}{*}{ Parameter } & \multicolumn{2}{|c|}{ Mean } & \multicolumn{2}{|c|}{$\begin{array}{c}\text { Standard Error } \\
\text { of Mean }\end{array}$} & \multirow[t]{3}{*}{$\mathrm{t}$} & \multirow[t]{3}{*}{ Significance } \\
\hline & & \multicolumn{2}{|c|}{ Period } & \multicolumn{2}{|c|}{ Period } & & \\
\hline & & $\begin{array}{c}30 \\
\text { days }\end{array}$ & $\begin{array}{c}60 \\
\text { days }\end{array}$ & $\begin{array}{c}30 \\
\text { days }\end{array}$ & $\begin{array}{c}60 \\
\text { days }\end{array}$ & & \\
\hline 1. Ele & ical conductivity, $\mathrm{dsm}^{-1}$ & 7.696 & 10.18 & 0.5141 & 0.7291 & -5.156 & $0.036<0.05$ \\
\hline 2. $\mathrm{Bu}$ & lensity $\times 10^{-3} \mathrm{~kg} \mathrm{~m}^{-3}$ & 0.2342 & 0.2579 & 0.0073 & 0.0160 & -2.270 & 0.114 \\
\hline 3. $\mathrm{Mc}$ & ure content, $\%$ & 13.42 & 17.20 & 1.115 & 0.8103 & -12.34 & 0.006 \\
\hline 4. $\mathrm{W}$ & holding capacity $\%$ & 136.2 & 156.6 & 16.68 & 13.39 & -3.264 & 0.082 \\
\hline 5. $\mathrm{pH}$ & & 7.530 & 7.306 & 0.0458 & 0.0409 & 25.32 & 0.002 \\
\hline 6. Тo & phosphorous, $\%$ & 0.220 & 0.361 & 0.0360 & 0.0231 & -8.630 & 0.01 \\
\hline 7. Тo & potassium. \% & 1.600 & 1.760 & 0.0378 & 0.0305 & -16.00 & 0.004 \\
\hline 8. To & magnesium, \% & 0.3866 & 0.4000 & 0.0384 & 0.0351 & -4.000 & 0.057 \\
\hline 9. To & sodium, \% & 0.266 & 0.283 & 0.0066 & 0.0088 & -5.000 & 0.038 \\
\hline 10. To & nitrogen, $\%$ & 0.650 & 1.32 & 0.0832 & 0.0874 & -5.320 & 0.034 \\
\hline
\end{tabular}

Pearson correlations are presented in Tables 4 and 5 for physical and chemical parameters respectively. At the intersection of any row and column parameters, the values having single star superscript indicates either positive or negative correlation depending upon the sign. This is significant at 5 percent level. The double star super script points out that the correlation is significant at 1 percent level. To cite one example in each of the parameter it is observed that there is positive correlation of EC with $\mathrm{MC}$ and WHC. pH has been found to correlate negatively with total nitrogen and total potassium.

Table 4. Pearson correlation for physical parameters

\begin{tabular}{ccccc}
\hline & EC & BD & MC & WHC \\
\hline EC & 1 & 0.115 & $0.914^{*}$ & $0.814^{*}$ \\
BD & 0.115 & 1 & 0.025 & -0.401 \\
MC & $0.914^{*}$ & 0.025 & 1 & $0.866^{*}$ \\
WHC & $0.814^{*}$ & -0.401 & $0.866^{*}$ & 1 \\
\hline
\end{tabular}

${ }^{*}$ Correlation is significant at 5 percent level; ${ }^{* *}$ Correlation is significant at 1 percent level

Table 5. Pearson correlation for chemical parameters

\begin{tabular}{cccccccc}
\hline & $\mathrm{pH}$ & Total N & Total P & Total K & Total Ca & Total Mg & Total Na \\
\hline $\mathrm{pH}$ & 1 & $-0.897^{*}$ & -0.653 & $-0.881^{*}$ & -0.533 & -0.196 & -0.307 \\
Total N & $-0.897^{*}$ & 1 & 0.714 & 0.775 & 0.493 & 0.003 & 0.437 \\
Total P & -0.653 & 0.714 & 1 & $0.869^{*}$ & $0.918^{* *}$ & 0.521 & $0.891^{*}$ \\
Total K & $-0.881^{*}$ & 0.775 & $0.869^{*}$ & 1 & $0.852^{*}$ & 0.583 & 0.669 \\
Total $\mathrm{Ca}$ & -0.533 & 0.493 & $0.918^{* *}$ & $0.852^{*}$ & 1 & 0.707 & $0.910^{*}$ \\
Total $\mathrm{Mg}$ & -0.196 & 0.003 & 0.521 & 0.583 & 0.707 & 1 & 0.619 \\
Total Na & -0.307 & 0.437 & $0.891^{*}$ & 0.669 & $0.910_{*}^{*}$ & 0.619 & 1 \\
\hline
\end{tabular}

"Correlation is significant at 5 percent level; ${ }^{* *}$ Correlation is significant at 1 percent level

\section{Conclusion}

Composted samples containing cow dung slurry with Jatropha in different proportions are prepared. Each of the samples after maturity for a period of 30 and 60 days has been subjected to the analysis of physicochemical parameters. The results indicate that an increase 
in the percentage of macronutrients as days of composting extended. $\mathrm{pH}$ has been found to decrease while variations have been observed in other parameters studied. An indication of maturity of the samples has been assessed based on these observations.

\section{References}

1. Nenhwu Zhu, Bioresource Technology, 2006, 97(15), 1870-1875.

2. Imbeah M, Bioresource Technology, 1998, 63, 197-203.

3. Swati Pattnaik and Vikram Reddy M, Resour Conservat Recycl., 2010, 54(8), 210-520.

4. Jackson M.L, Prentice Hall of India Pvt Ltd New Delhi, 1973.

5. Pam Pittaway, Slizankiewicz V and Spence M, National Center for Engineering in Agriculture, University of Southern Queensland, Toowoomba, NECA Publication, 179714/1, 2001.

6. Peter J Stofftella and Brian A Khan (Eds), Compost Utilization in Horticultural Cropping System, CRC Press, Print ISBN: 978-1-56670-460-1, 2001. Chapter - 2.

7. Jeevan Rao.K, Proceedings of the International Conference on Sustainable Solid Waste Management 2007, 244-249.

8. Conception Mendoza. S and Janice Jamora.B, Philipp Scient, 2008, 45, 123.

9. Srinath R. Iyengar and Prashant P. Bhave, Waste Management, 2006, 26(10), 1070-1080.

10. Elango D, Thinakaran N, Panneerselvam P and Sivanesan S, Applied Energy, 2009, 86(5), 663-668.

11. Haimi J and Huhta V, Biol Fert Soils, 1986, 2, 23 - 27.

12. Senesi, N, Sci Total Environ., 1989, 81, 521 -542. 


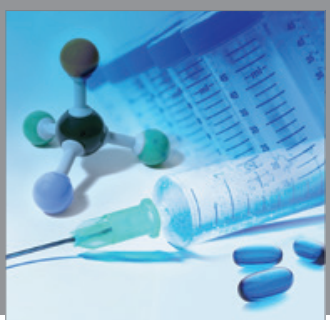

International Journal of

Medicinal Chemistry

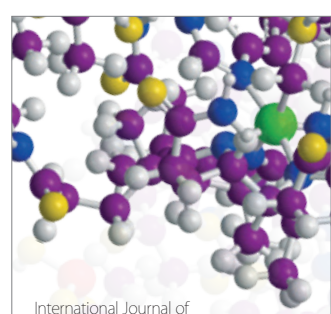

Carbohydrate Chemistry

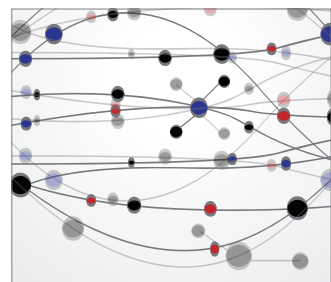

The Scientific World Journal
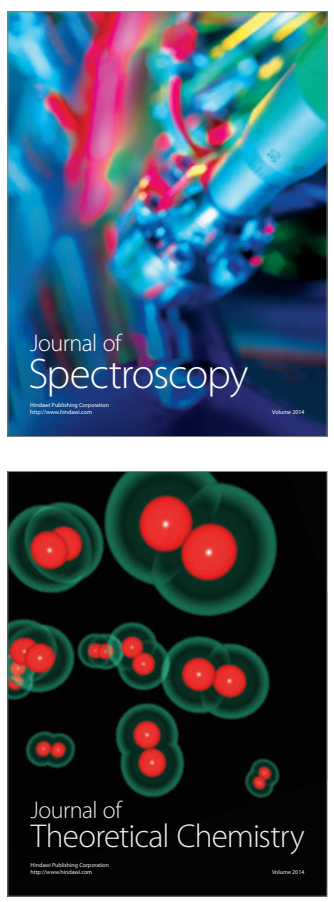
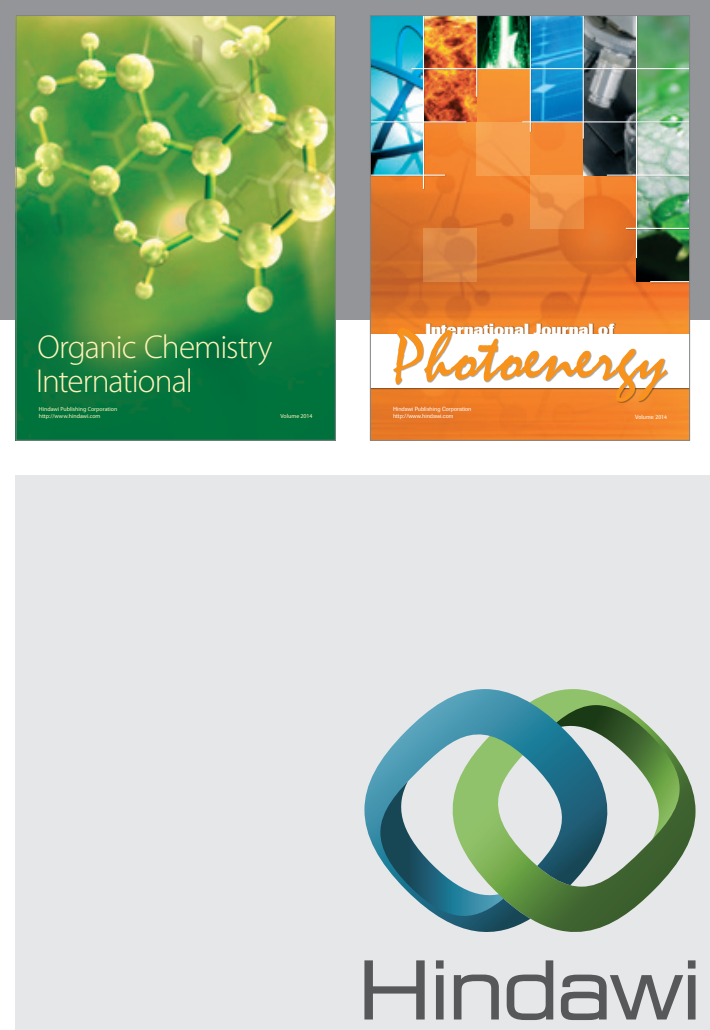

Submit your manuscripts at

http://www.hindawi.com
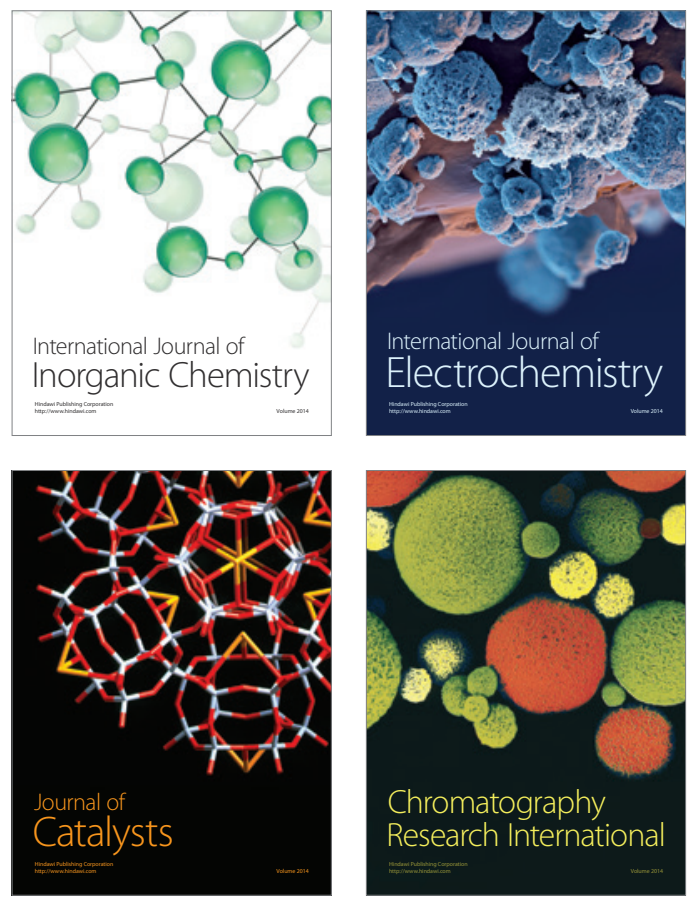
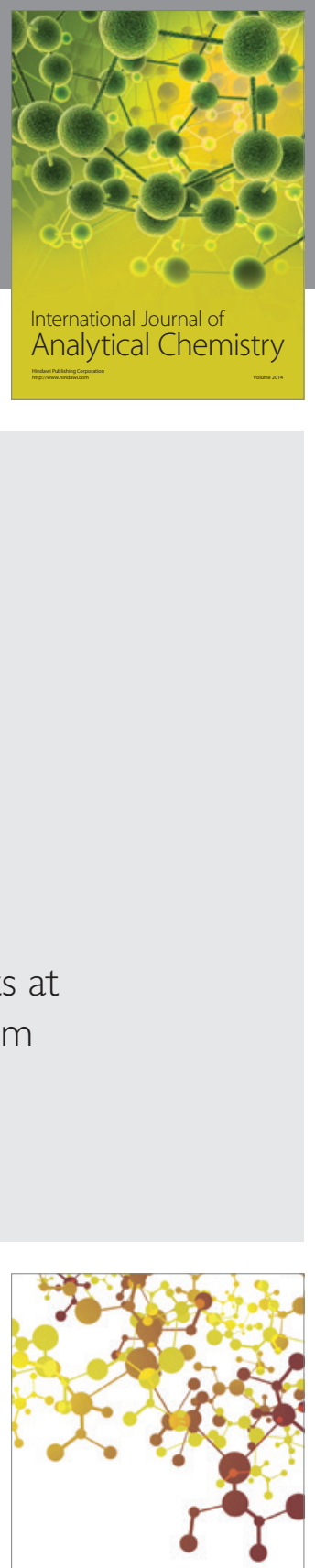

Journal of

Applied Chemistry
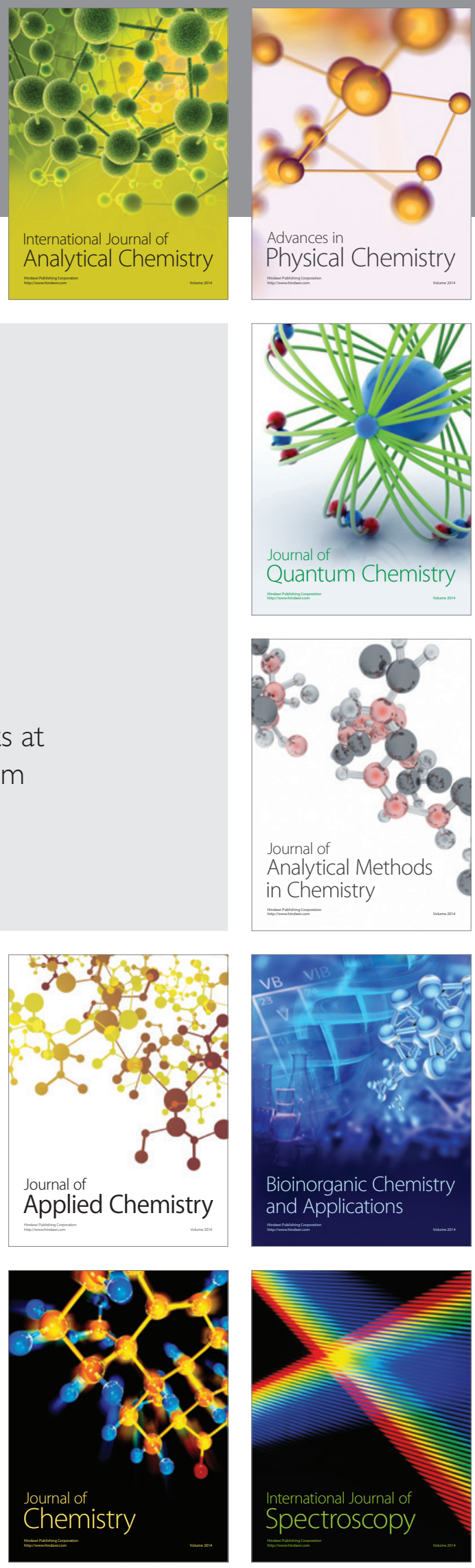